\title{
Triton WR-1339-induced hyperlipidemia, DNA fragmentation, neurotransmitters inhibition, oxidative damage, histopathological and morphometric changes: the protective role of soybean oil
}

\author{
Heba Mohamed Abdou ${ }^{1 *}$, Mokhtar Ibrahim Yousef ${ }^{2}$ and Alsayeda Alsayed Newairy ${ }^{3}$
}

\begin{abstract}
Background: Triton WR1339 (Tyloxapol) is the nonionic detergent, which is able to increase the oxidative markers. This oxidation have a crucial effect on the pathological processes. Vegetable oils, such as soy, are recommended for human consumption due to the presence of high content of monounsaturated fatty acids (MUFA) and polyunsaturated fatty acids (PUFA). Therefore, the effect of Triton WR1339 and soybean oil on biochemical parameters was tested in our study.

Aim: The objective of this study is to investigate the possible protective effects of soybean oil against Triton WR1339-induced hyperlipidemia, DNA fragmentation, oxidative damage, neurotransmitters inhibition, and changes in histological and morphometric analysis of the liver and dorsal aorta of male rats.

Methods: Animals were treated with Triton WR-1339 (50 mg/kg BW) and soybean oil (50 mg/kg BW) for 28 days. Oxidative stress markers; antioxidant enzymes activity; biochemical parameters, such as acetylcholinesterase and mono aminoxidase, transaminases, phosphatases, lactate dehydrogenase, urea, creatinine, bilirubin, and lipid profile; DNA fragmentation; as well as histopathological and morphmetric analysis of the liver and dorsal aorta were investigated.
\end{abstract}

Results: Triton WR-1339 increased oxidative stress through an elevation in TBARS associated with depletion in glutathione and the activities of GST, SOD, GSH-Px, and CAT in plasma, liver, and brain. Triton WR-1339 induced DNA fragmentation and inhibited the activities of acetylcholinesterase and mono aminoxidase in the brain. Plasma biochemical parameters including transaminases, phosphatases, lactate dehydrogenase, urea, creatinine, bilirubin, total lipid, cholesterol, triglyceride, and LDL were increased, while total protein, albumin, and high HDL were decreased due to Triton WR-1339-treatment. The histopathological and morphmetric analysis of the liver and dorsal aorta revealed alterations after Triton WR-1339-treatment. The presence of soybean oil with Triton WR-1339 minimized its hepatotoxicity and neurotoxicity via hypolipidemic effects and attenuated the oxidative damage.

Conclusion: Soybean oil showed hypolipidemic effects and antioxidant activity, so it could be used as a hypolipidemic agent.

Keywords: Triton WR-1339, Rats, Lipid peroxidation, Soybean oil, DNA fragmentation

\footnotetext{
*Correspondence: dr.heba_abdou3000@yahoo.com

'Zoology Department, Faculty of Science, Alexandria University, Alexandria,

Egypt

Full list of author information is available at the end of the article
} 


\section{Background}

Triton WR-1339 (Tyloxapol) has been used to induce hyperlipidemia in animals (Pushpa \& Jayachitra, 2015). The liver is the major organ responsible for cholesterol transport, metabolism, and excretion (Da Rocha, Sperança, Nogueira, \& Zeni, 2009). Hyperlipidemia is characterized by elevated serum total cholesterol, low-density cholesterol, and very low density lipoprotein cholesterol and decreased high-density lipoprotein cholesterol levels (Ibrahim, Mohamed, Banjar, \& Kamal, 2013). The increase of oxidative metabolic activity in addition to the low concentrations of the endogenous antioxidants causes liver and brain oxidative damage (Abdou \& Wahby, 2016; Küçükgergin et al., 2010). Currently, available hypolipidemic drugs have been associated with a number of side effects (Al-Awadi, Rashid, \& Hassen, 2013b).

Nowadays, different natural supplements from plant origin are used as a complementary supplement in the treatment of many diseases by improving the efficacy of drug used or by minimizing the toxic side effect and so enhancing the state (Salem et al., 2012). Plants and many plant-derived preparations have long been earlier used as traditional remedies for the treatment of hyperlipidemia in many parts of the world. The use and especially the consumption of phytochemicals have been rapidly increasing worldwide (Sunil, Ignacimuthu, \& Kumarappan, 2012). Vegetable oils, such as soy, are recommended for human consumption due to their high content of monounsaturated fatty acids (MUFA) and polyunsaturated fatty acids (PUFA) (Chahoud, Aude, \& Mehta, 2004).

Soy oil, which is produced from soybean, is the most widely marketed edible oil in the world (Hayes \& Khosla, 2007). Soy oil contains approximately $60 \%$ of PUFA, $24 \%$ of MUFA, and $16 \%$ of saturated fatty acids (Warner, 2005). In addition, soy oil is known to exhibit various antioxidant actions against lipid peroxidation (Zainuddin, Massi, Alam, Djawad, \& Yusuf, 2015). Therefore, the present study was undertaken to investigate (1) the hypolipidemic potential of the soybean oil in a model of hyperlipidemia induced by Triton WR-1339 in male rats, (2) the antioxidant effects of soybean oil in the liver and brain tissues, and (3) the protective role of soybean oil against the oxidative damage through the examination of important biomarkers in addition to histological investigations and (DNA) fragmentation.

\section{Materials and methods \\ Chemicals}

Triton WR-1339 (Tyloxapol) was purchased from Sigma-Aldrich Co. USA. Soybean oil was obtained commercially from the Imtenan Health Company, Egypt. All other chemicals were of analytical grade. The reagent kits for aspartate aminotransaminase (AST), alanine amino transaminase (ALT), lactate dehydrogenase
$(\mathrm{LDH})$, acid phosphatase (ACP), alkaline phosphatase (ALP), enzyme activities, and total protein, albumin, urea, creatinine, bilirubin, and lipid profile concentrations were purchased from Sentinel Ch. (Via Principle Eugenio 5-20155 Milan, Italy).

\section{Animals and experimental groups}

Twenty-one adult male Wistar rats, aged 11-12 weeks weighing 180-200 g, were used in the present experiments. Animals were obtained from Faculty of Medicine, Alexandria University, Alexandria, Egypt. The local committee approved the design of the experiments, and the protocol conforms to the guidelines of the National Institutes of Health (NIH). Animals were caged in groups and given food and water ad libitum. After 2 weeks of acclimation, animals were divided randomly into three groups; seven rats in each group. Group I (control group) rats were treated with a vehicle (injected intraperitoneally with saline and treated orally with corn oil). Group II was injected intraperitoneally with $50 \mathrm{mg} / \mathrm{kg}$ BW of Triton WR-1339 every other day. Group III was treated orally with $50 \mathrm{mg} / \mathrm{kg} \mathrm{BW}$ of soybean oil every day plus $50 \mathrm{mg} / \mathrm{kg}$ BW of Triton WR-1339 every other day. The dose of Triton WR-1339 was chosen according to Bhuvaneswari and Sasikumar (2013). The dose of soybean oil was chosen according to Mallo et al. (2013a, b). Rats were administered their respective doses for 28 days.

\section{Blood collection and tissue preparation}

At the end of the 28th day of the experimental period, all animals of each group were anesthetized with ether and sacrificed. Blood samples were collected from anesthetized rats in test tubes containing heparin as an anticoagulant and placed immediately on ice. Plasma samples were obtained by centrifugation at $860 \times g$ for 20 min using cooling centrifuge (Hettich, Germany) and stored at $-80{ }^{\circ} \mathrm{C}$. Stored plasma samples were analyzed for the activities of the antioxidant enzymes (glutathione-S-transferase, GST; superoxide dismutase, SOD; catalase, CAT; and glutathione peroxidase, GSH-Px) and the marker of lipid peroxidation (thiobarbituric acid-reactive substances, TBARS).

Pieces of liver and brain were immediately removed, and washed using the chilled saline solution. Tissues were minced and homogenized $(10 \% w / v)$, separately, in ice-cold sodium, potassium phosphate buffer $(0.01 \mathrm{M}$, $\mathrm{pH} 7.4$ ) containing $1.15 \% \mathrm{KCl}$ in a Potter-Elvehjem type homogenizer. The homogenate was centrifuged at $10,000 \times g$ for $20 \mathrm{~min}$ at $4{ }^{\circ} \mathrm{C}$. The resulting supernatant was used for the determination of the enzyme activities and the levels of TBARS, reduced glutathione (GSH), and protein. Other pieces from liver and pieces from aorta were fixed immediately in $10 \%$ formalin for the histological studies. 
Tissue and plasma thiobarbituric acid reactive substances and antioxidant enzymes

Thiobarbituric acid-reactive substances (TBARS) were assayed in the plasma and the tissue extracts at $532 \mathrm{~nm}$ by using a 2-thiobarbituric acid (2,6-dihydroxypyrimidine-2-thiol, TBA). An extinction coefficient of $156,000 \mathrm{M}^{-1} \mathrm{~cm}^{-1}$ was used for calculation (Esterbauer and Cheeseman, 1990). Reduced glutathione content was assayed by the method of Beutler, Duron, and Kelly (1963). The method utilized metaphosphoric acid for protein precipitation and 5,5-dithiobis (2-nitrobenzoic acid) (DTNB) for color development and its density was measured at $412 \mathrm{~nm}$. Glutathione-S-transferase (GST; EC 2.5.1.18) catalyzes the conjugation reaction with glutathione in the first step of mercapturic acid synthesis. The activity of GST was measured according to the method of Habig, Pabst, and Jakoby (1974). P-nitrobenzylchloride was used as substrate. The absorbance was measured spectrophotometrically at $310 \mathrm{~nm}$ using UV-Double Beam Spectrophotometer (Model: Evolution 300 UV-Vis, USA). The catalase enzyme (CAT; EC 1.11.1.6) converts $\mathrm{H}_{2} \mathrm{O}_{2}$ into water. The CAT activity in plasma and tissue extracts was measured spectrophotometrically at $240 \mathrm{~nm}$ by calculating the rate of degradation of $\mathrm{H}_{2} \mathrm{O}_{2}$, the substrate of the enzyme (Xu, Yuan, \& Lang, 1997). Superoxide dismutase (SOD; EC 1.15.1.1) was assayed according to Misra and Fridovich (1972). The assay procedure involves the inhibition of epinephrine autooxidation in an alkaline medium $(\mathrm{pH} 10.2)$ to adrenochrome, which is markedly inhibited by the presence of SOD. Epinephrine was added to the assay mixture, containing tissue supernatant and the change in extinction coefficient was followed at $480 \mathrm{~nm}$ in a spectrophotometer. Glutathione peroxidase (GPx; EC 1.1.1.9) activity was assayed using the method of Chiu, Stults, and Tappel (1976).

\section{Plasma and brain acetylcholinesterase and monoamine oxidase estimation}

Acetylcholinesterase (AChE; EC 3.1.1.7) activity was estimated in plasma and tissue supernatant using acetylcholine iodide as a substrate according to the method of Ellman, Courtney, Anders, and Featherstone (1961). The activity of monoamine oxidase was estimated in plasma and tissue extracts according to the method of Sandler, Reveley, and Glover (1981).

\section{Protein estimation}

The protein content of the tissue extracts mentioned earlier was determined by the method of Lowry, Rosebrough, Farr, and Randall (1951) using bovine serum albumin as a standard.

\section{Biochemical parameters}

Plasma and liver aspartate aminotransaminase (AST; EC 2.6.1.1), alanine aminotransaminase (ALT; EC 2.6.1.2), and lactate dehydrogenase (LDH; EC 1.1.1.27) activities were determined using kits from SENTINEL CH. (Via Principle Eugenio 5-20155 Milan, Italy). Stored plasma samples were analyzed for urea and creatinine concentrations using kits from SENTINEL CH. (Via Principle Eugenio 5-20155 Milan, Italy).

Plasma total cholesterol, high-density lipoproteins (HDL), and triglyceride levels were estimated by using cholesterol and triglyceride kits, span diagnostics Ltd., India. The assays were performed in accordance with the manufacturer's instructions.

\section{Histological section preparation}

Specimens of liver and aorta tissues were immediately fixed in $10 \%$ formalin, and then treated with conventional grade of alcohol and xylol, embedded in paraffin , sectioned at 4-6 $\mu$ thickness. The sections were stained with hematoxylin and eosin $(\mathrm{H} \& \mathrm{E})$ stain for studying the histopathological changes (Lillie, 1965). The ImageJ analyzer software was used for morphometric analysis of dorsal aorta thickness.

\section{Qualitative DNA fragmentation assay using agarose gel electrophoresis}

DNA was extracted using the genomic DNA purification kit purchased from Bio Basic Inc., Canada. Afterwards, DNA was quantified spectrophotometrically and then loaded onto agarose gel. DNA laddering was determined by constant voltage mode electrophoresis at $80 \mathrm{~V}$, for $45 \mathrm{~min}$ on a $1.2 \%$ agarose gel containing $0.5 \mu \mathrm{g} / \mathrm{ml}$ ethidium bromides. Gels were illuminated with $300 \mathrm{~nm}$ UV light and a photographic record was made (Miller, Dykes, \& Polesky, 1988).

\section{Statistical analysis}

Results were reported as means $\pm \mathrm{SE}$. The statistical significance of the difference in values of control and treated animals was calculated by one-way analysis of variance (ANOVA) using SPSS version 22 (SPSS, IBM, USA) and post-hoc comparisons between groups were obtained by Duncan's multiple range test (DMRT). Values were considered statistically significant when $P$ $<0.05$ (Duncan, 1957).

\section{Results}

Effects of Triton WR-1339 and soybean oil and their combination on lipid peroxidation and antioxidant enzymes

Results in Tables 1, 2 and 3 indicated that the treatment with Triton WR-1339 caused a significant $(P<0.05)$ elevation in the levels of TBARS combined with an inhibition of 
Table 1 The effect of soybean oil (SBO), Triton WR-1339, and their combination on plasma TBARS, GSH, GPx, GST, CAT, and SOD in male rats compared to a control group

\begin{tabular}{llll}
\hline Parameter & \multicolumn{3}{l}{ Experimental groups } \\
\cline { 2 - 4 } & Control & Triton & Triton + SBO \\
\hline TBARS & $0.52 \pm 0.04$ & $0.99 \pm 0.03^{\mathrm{a}}$ & $0.67 \pm 0.045^{\mathrm{b}}$ \\
GSH & $0.38 \pm 0.012$ & $0.12 \pm 0.01^{\mathrm{a}}$ & $0.23 \pm 0.020^{\mathrm{ab}}$ \\
GPX & $18.1 \pm 1.12$ & $9.9 \pm 0.47^{\mathrm{a}}$ & $14.9 \pm 0.81^{\mathrm{ab}}$ \\
GST & $2.01 \pm 0.13$ & $1.13 \pm 0.09^{\mathrm{a}}$ & $1.72 \pm 0.087^{\mathrm{ab}}$ \\
CAT & $48 \pm 2.43$ & $27 \pm 1.98^{\mathrm{a}}$ & $39 \pm 3.01^{\mathrm{ab}}$ \\
SOD & $3.24 \pm 0.201$ & $1.54 \pm 0.09^{\mathrm{a}}$ & $2.43 \pm 0.089^{\mathrm{ab}}$ \\
\hline
\end{tabular}

Values are expressed as means $\pm \mathrm{SE}$

TBARS thiobarbituric acid reactive substance $(\mathrm{nmol} / \mathrm{ml}), G S H$ glutathione $(\mathrm{U} / \mathrm{ml})$, GPx glutathione peroxidase $(\mathrm{U} / \mathrm{ml})$, GST glutathione S-transferase $(\mu \mathrm{mol} / \mathrm{hr} . / \mathrm{ml})$, CAT catalase $\left(\mu \mathrm{mol} \mathrm{H}_{2} \mathrm{O}_{2}\right.$ consumed $\left./ \mathrm{min} / \mathrm{ml}\right), S O D$ superoxide dismutase $(\mathrm{U} / \mathrm{ml})$ ${ }^{a}$ The mean values are significantly different compared to a control group at $P<0.05$

${ }^{\mathrm{b}}$ The mean values are significantly different compared to Triton-intoxicated group at $P<0.05$

the antioxidant enzymes (GPx, GST, CAT, SOD) in rat plasma, liver, and brain. This disturbance was also manifested by a significant decrease in the level of GSH $(P<$ $0.05)$ in plasma and both organs. The most striking finding in this study is that the presence of soybean oil with Triton WR-1339 alleviated its harmful effects on GSH, TBARS, GPx, GST, CAT, and SOD in rat plasma, liver, and brain (Tables 1, 2 and 3) and returned near to the control values.

\section{Effects of Triton WR-1339, soybean oil, and their combination on the biochemical parameters}

The data shown in Table 4 demonstrated that treatment with Triton WR-1339 caused a significant $(P<0.05)$ decline in the activities of AST, ALT, ALP, ACP, and LDH in the liver and elevation in plasma. In addition, Triton WR-1339 caused significant $(P<0.05)$ decreases in the activities of the $\mathrm{AChE}$ and MAO enzymes in rat plasma and brain. Triton

Table 2 The effect of soybean oil (SBO), Triton WR-1339, and their combination on the liver and brain content of TBARS and GSH in male rats compared to a control group

\begin{tabular}{|c|c|c|c|}
\hline \multirow[t]{2}{*}{ Parameter } & \multicolumn{3}{|c|}{ Experimental groups } \\
\hline & Control & Triton & Triton + SBO \\
\hline \multicolumn{4}{|l|}{ Liver } \\
\hline TBARS & $30.20 \pm 1.05$ & $59.23 \pm 2.16^{a}$ & $36.90 \pm 1.99^{\mathrm{ab}}$ \\
\hline GSH & $6.87 \pm 0.14$ & $3.11 \pm 0.10^{\mathrm{a}}$ & $4.67 \pm 0.23^{\mathrm{ab}}$ \\
\hline \multicolumn{4}{|l|}{ Brain } \\
\hline TBARS & $43.90 \pm 1.15$ & $70.20 \pm 2.15^{a}$ & $53.54 \pm 1.99^{\mathrm{ab}}$ \\
\hline GSH & $5.43 \pm 0.25$ & $2.99 \pm 0.13^{\mathrm{a}}$ & $4.12 \pm 0.32^{\mathrm{ab}}$ \\
\hline
\end{tabular}

Values are expressed as means $\pm \mathrm{SE}$

TBARS thiobarbituric acid reactive substances ( $\mathrm{nmol} / \mathrm{g}$ tissue), $\mathrm{GSH}$ reduced glutathione ( $\mu \mathrm{mol} / \mathrm{g}$ tissue)

${ }^{a}$ The mean values are significantly different compared to a control group at $P<0.05$

${ }^{\mathrm{b}}$ The mean values are significantly different compared to triton-intoxicated group at $P<0.05$
Table 3 The effect of soybean oil (SBO), Triton WR-1339, and their combination on liver and brain antioxidant enzymes in male rats compared to a control group

\begin{tabular}{|c|c|c|c|}
\hline \multirow[t]{2}{*}{ Parameters } & \multicolumn{3}{|c|}{ Experimental groups } \\
\hline & Control & Triton & Triton + SBO \\
\hline \multicolumn{4}{|l|}{ Liver } \\
\hline GPX & $38.8 \pm 0.89$ & $21.4 \pm 0.91^{a}$ & $32.2 \pm 1.21^{\mathrm{ab}}$ \\
\hline GST & $1.12 \pm 0.03$ & $0.62 \pm 0.04^{a}$ & $0.89 \pm 0.03^{\mathrm{ab}}$ \\
\hline CAT & $49.1 \pm 1.21$ & $30.6 \pm 1.12^{a}$ & $41 \pm 0.99^{\mathrm{ab}}$ \\
\hline SOD & $12.2 \pm 0.54$ & $7.1 \pm 0.22^{\mathrm{a}}$ & $9.2 \pm 0.32^{\mathrm{ab}}$ \\
\hline \multicolumn{4}{|l|}{ Brain } \\
\hline GPX & $25.1 \pm 1.55$ & $16.9 \pm 0.98^{a}$ & $21.9 \pm 1.21^{\mathrm{ab}}$ \\
\hline GST & $0.38 \pm 0.02$ & $0.18 \pm 0.01^{a}$ & $35.8 \pm 2.21^{\mathrm{ab}}$ \\
\hline CAT & $40.2 \pm 2.56$ & $27.8 \pm 1.99^{a}$ & $9.87 \pm 0.62^{\mathrm{ab}}$ \\
\hline SOD & $11.12 \pm 0.86$ & $6.98 \pm 0.55^{\mathrm{a}}$ & $0.29 \pm 0.02^{\mathrm{ab}}$ \\
\hline
\end{tabular}

Values are expressed as means $\pm \mathrm{SE}$

GPx glutathione peroxidase (U/mg protein), GST glutathione S-transferase ( $\mu \mathrm{mol} / \mathrm{h} / \mathrm{mg}$ protein), $C A T$ catalase $\left(\mu \mathrm{mol} \mathrm{H}_{2} \mathrm{O}_{2}\right.$ consumed $/ \mathrm{min} / \mathrm{mg}$ protein), $S O D$ superoxide dismutase ( $\mathrm{U} / \mathrm{mg}$ protein)

${ }^{a}$ The mean values are significantly different compared to a control group at $P<0.05$

${ }^{\mathrm{b}}$ The mean values are significantly different compared to triton-intoxicated group at $P<0.05$

WR-1339 caused also a significant decline in total protein, albumin, and globulin, and increase in urea, creatinine, and bilirubin in plasma. On the other hand, AST, ALT, ALP, ACP, and LDH were significantly $(P<0.05)$ increased in liver and decreased in plasma after treatment with Triton WR-1339 plus soybean oil, compared to the Triton WR-1339-treated group. However, rats treated with soybean oil and Triton WR-1339 exhibited a significant $(P<0.05)$ increase in the levels of total protein, albumin, globulin, acetylcholinesterase, and monoamine oxidase. The presence of soybean oil and Triton WR-1339 leads to significant $(P$ $<0.05)$ reduction in the plasma urea, creatinine, and bilirubin compared to rats treated with Triton WR-1339 alone.

\section{Effects of Triton WR-1339, soybean oil, and their combination on plasma lipid profile}

Table 5 showed the lipid profile of all the studied groups in this study. The results showed that the treatment of rats with Triton WR-1339 induced significant $(P<0.05)$ increases in the plasma total lipids from $545 \pm 16.4$ to $628 \pm 23.5$, total cholesterol from $145 \pm 5.8$ to $205 \pm 7.1$, LDL from $75.5 \pm 2.23$ to $145.6 \pm 2.76$, VLDL from $24.6 \pm$ 0.98 to $36.2 \pm 1.32$, and TAG from $123 \pm 4.01$ to $181 \pm$ 3.99. While, HDL level was significantly decreased compared to the control group (from $44.9 \pm 2.11$ to $23.2 \pm$ 1.46). On the other hand, treatment with Triton WR-1339 plus soybean oil showed amelioration in the levels of plasma total lipids, total cholesterol, HDL, LDL, TAG, and VLDL $(578 \pm 23.6,175 \pm 8.9,34.2 \pm 2.01$, $111.6 \pm 3.07,146 \pm 5.11$, and $29.2 \pm 1.12$, respectively). 
Table 4 The effect of soybean oil (SBO), Triton WR-1339, and their combination on plasma, liver, and brain biochemical parameters in male rats compared to a control group

\begin{tabular}{|c|c|c|c|}
\hline \multirow[t]{2}{*}{ Parameters } & \multicolumn{3}{|c|}{ Experimental groups } \\
\hline & Control & Triton & Triton + SBO \\
\hline \multicolumn{4}{|l|}{ Plasma } \\
\hline AST & $34.8 \pm 1.34$ & $65.8 \pm 2.09^{\mathrm{a}}$ & $45.5 \pm 1.42^{\mathrm{ab}}$ \\
\hline ALT & $29.8 \pm 0.98$ & $59.1 \pm 1.56^{\mathrm{a}}$ & $39.9 \pm 1.23^{\mathrm{ab}}$ \\
\hline ACP & $8.32 \pm 0.43$ & $16.89 \pm 0.64^{a}$ & $11.12 \pm 0.53^{\mathrm{ab}}$ \\
\hline ALP & $39.8 \pm 1.76$ & $73.9 \pm 1.43^{\mathrm{a}}$ & $51.8 \pm 1.65^{\mathrm{ab}}$ \\
\hline LDH & $985 \pm 10.80$ & $1789 \pm 15.9^{a}$ & $1298 \pm 20.9^{a b}$ \\
\hline MAO & $30.1 \pm 1.10$ & $19.9 \pm 1.021^{a}$ & $25.1 \pm 2.23^{b}$ \\
\hline $\mathrm{AChE}^{*}$ & $2.98 \pm 0.12$ & $2.32 \pm 0.09^{a}$ & $2.64 \pm 0.11^{b}$ \\
\hline T.P & $7.8 \pm 0.34$ & $4.5 \pm 0.35^{\mathrm{a}}$ & $5.8 \pm 0.252^{\mathrm{ab}}$ \\
\hline Albumin & $4.9 \pm 0.12$ & $2.9 \pm 0.11^{a}$ & $3.9 \pm 0.13^{\mathrm{ab}}$ \\
\hline Globulin & $2.9 \pm 0.12$ & $1.6 \pm 0.08^{\mathrm{a}}$ & $1.9 \pm 0.20^{\mathrm{ab}}$ \\
\hline Urea & $36.9 \pm 1.26$ & $50.1 \pm 1.23^{\mathrm{a}}$ & $41.2 \pm 1.53^{\mathrm{ab}}$ \\
\hline Creatinine & $0.95 \pm 0.05$ & $1.69 \pm 0.06^{\mathrm{a}}$ & $1.29 \pm 0.07^{\mathrm{ab}}$ \\
\hline Bilirubin & $1.52 \pm 0.06$ & $2.82 \pm 0.07^{\mathrm{a}}$ & $1.79 \pm 0.04^{\mathrm{ab}}$ \\
\hline \multicolumn{4}{|l|}{ Liver } \\
\hline AST & $99.1 \pm 3.11$ & $50.9 \pm 2.98^{\mathrm{a}}$ & $82.9 \pm 3.27^{\mathrm{ab}}$ \\
\hline ALT & $69.9 \pm 2.98$ & $42.1 \pm 2.12^{\mathrm{a}}$ & $58.7 \pm 2.32^{\mathrm{ab}}$ \\
\hline ALP & $223 \pm 11.2$ & $131 \pm 7.1^{\mathrm{a}}$ & $186 \pm 9.90^{\mathrm{ab}}$ \\
\hline $\mathrm{ACP}$ & $21.5 \pm 0.98$ & $9.9 \pm 0.56^{a}$ & $16.8 \pm 0.78^{\mathrm{ab}}$ \\
\hline LDH & $1760 \pm 54$ & $1279 \pm 43^{a}$ & $1589 \pm 39^{\mathrm{ab}}$ \\
\hline P.C & $125 \pm 4.10$ & $87 \pm 2.3^{a}$ & $108 \pm 3.81^{\mathrm{ab}}$ \\
\hline \multicolumn{4}{|l|}{ Brain } \\
\hline $\mathrm{AChE}^{* *}$ & $14.97 \pm 0.52$ & $10.78 \pm 0.41^{a}$ & $12.91 \pm 0.210^{\mathrm{ab}}$ \\
\hline $\mathrm{LDH}$ & $1210 \pm 35$ & $760 \pm 29^{a}$ & $989 \pm 23^{\mathrm{ab}}$ \\
\hline MAO & $6.99 \pm 0.23$ & $3.21 \pm 0.13^{\mathrm{a}}$ & $4.89 \pm 0.09^{b}$ \\
\hline P.C & $89 \pm 2.34$ & $68 \pm 3.21^{a}$ & $78 \pm 1.99^{b}$ \\
\hline
\end{tabular}

Values are expressed as means $\pm \mathrm{SE}$

AST aspartate transaminases (U/L), liver AST (U/mg protein), $A L T$ alanine transaminases $(\mathrm{U} / \mathrm{L})$, liver $\mathrm{ALT}(\mathrm{U} / \mathrm{mg}$ protein), $A C P$ acid phosphatase $(\mathrm{U} / \mathrm{L})$, liver ACP (U/mg protein), ALP alkaline phosphatase (U/L) liver ALP (U/mg protein), $L D H$ lactate dehydrogenase (1 U/L), liver and brain $\mathrm{LDH}(\mathrm{IU} / \mathrm{g}), T . P$ total protein $(\mathrm{mg} / \mathrm{dl})$, *Plasma $A C h E$ acetylcholinesterase ( $\mu$ mole substrate hydrolyzed/ $\mu \mathrm{l}$ plasma/min), **Brain AChE $\mu$ mole substrate hydrolyzed $/ \mathrm{mg}$ protein $/ \mathrm{min}, M A O$ monoamine oxidase $(\mathrm{U} / \mathrm{g})$, P.C. protein content $(\mathrm{mg} / \mathrm{g}$ tissue), albumin $(\mathrm{g} / \mathrm{dl})$, globulin $(\mathrm{g} / \mathrm{dl})$, urea $(\mathrm{mg} / \mathrm{dl})$, creatinine $(\mathrm{mg} / \mathrm{dl})$, bilirubin $(\mathrm{mg} / \mathrm{dl})$

${ }^{a}$ The mean values are significantly different compared to a control group at $P<0.05$

${ }^{\mathrm{b}}$ The mean values are significantly different compared to triton-intoxicated group at $P<0.05$

\section{Histological examination}

The histological examination of the liver was represented in Fig. 1. The light micrographs of liver tissues demonstrated normal hepatocytes in the control group. While, in Triton WR-1339-treated group, hepatocytic damage was manifested by obvious fat vacuolation, the hepatic veins were dilated and congested with blood. Furthermore, the hepatocytic cells were necrosed.
Table 5 The effect of soybean oil (SBO), Triton WR-1339+ $\mathrm{SBO}$, and their combination on plasma total lipids (TL), cholesterol, high-density lipoprotein-cholesterol (HDL-c), low density lipoprotein-cholesterol (LDL-c), very low-density lipoprotein-cholesterol (VLDL-C), and triacyle glycerol (TAG) in male rats compared to a control group

\begin{tabular}{llll}
\hline $\begin{array}{lll}\text { Parameters } \\
(\mathrm{mg} / \mathrm{dl})\end{array}$ & \multicolumn{3}{l}{ Experimental groups } \\
\cline { 2 - 4 } & Control & Triton & Triton + SBO \\
\hline TL & $545 \pm 16.40$ & $628 \pm 23.5^{\mathrm{a}}$ & $578 \pm 23.6^{\mathrm{ab}}$ \\
Cholesterol & $145 \pm 5.80$ & $205 \pm 7.10^{\mathrm{a}}$ & $175 \pm 8.9^{\mathrm{ab}}$ \\
HDL-c & $44.9 \pm 2.11$ & $23.2 \pm 1.46^{\mathrm{a}}$ & $34.2 \pm 2.01^{\mathrm{ab}}$ \\
LDL-c & $75.5 \pm 2.23$ & $145.6 \pm 2.76^{\mathrm{a}}$ & $111.6 \pm 3.07^{\mathrm{ab}}$ \\
TAG & $123 \pm 4.01$ & $181 \pm 3.99^{\mathrm{a}}$ & $146 \pm 5.11^{\mathrm{ab}}$ \\
VLDL-c & $24.6 \pm 0.98$ & $36.2 \pm 1.32^{\mathrm{a}}$ & $29.2 \pm 1.12^{\mathrm{ab}}$
\end{tabular}

Values are expressed as means $\pm \mathrm{SE}$

${ }^{a}$ The mean values are significantly different compared to a control group at $P<0.05$

${ }^{\mathrm{b}}$ The mean values are significantly different compared to ttiton-intoxicated group at $P<0.05$

Abnormal localization and infiltration of hepatocytic nuclei were also appreciated. However, liver of rats treated with Triton WR-1339 + soybean oil detected that the most histological changes were reduced and attenuated from sever to moderate alterations compared to Triton WR-1339-induced changes. The results of the histopathological examination of the control group showed that dorsal aorta was normal as the intimal surface was smooth and continuous with a mean wall thickness equal 177.2 $\pm 0.26 \mu \mathrm{m}$ (Figs. 2 and 3 ). While, the histopathological examination of the dorsal aorta in Triton WR-1339-treated group showed a sclerotic changes in the walls and leanness of elastic fibers. This was assessed by the changes shown in the tunica intima and media as well as disintegration and vaculations in the tunica adventia. The quantitative analysis of the aortic composition of this group showed a significant $(P<0.05)$ increase in the mean wall thickness $(326.53 \pm$ $2.02 \mu \mathrm{m})$ as shown in Figs. 2 and 3. The morphometric analysis of the dorsal aorta of the combination group revealed a marked reduction of the histological alterations induced after Triton WR-1339 treatment. This could be confirmed by the significant $(P<0.05)$ decrease in the mean wall thickness $(179.86 \pm 0.81 \mu \mathrm{m})$ as shown in Fig. 3. The results of our study demonstrated that the histopathological changes induced in the dorsal aorta of Triton WR-1339-treated rats were markedly reduced in the rats treated with Triton WR-1339 + soybean oil (Fig. 2).

\section{Qualitative DNA fragmentation assay by agarose gel electrophoresis}

The DNA fragmentation of rat brain tissue was detected on agarose gel electrophoresis as shown in Fig. 4. The 

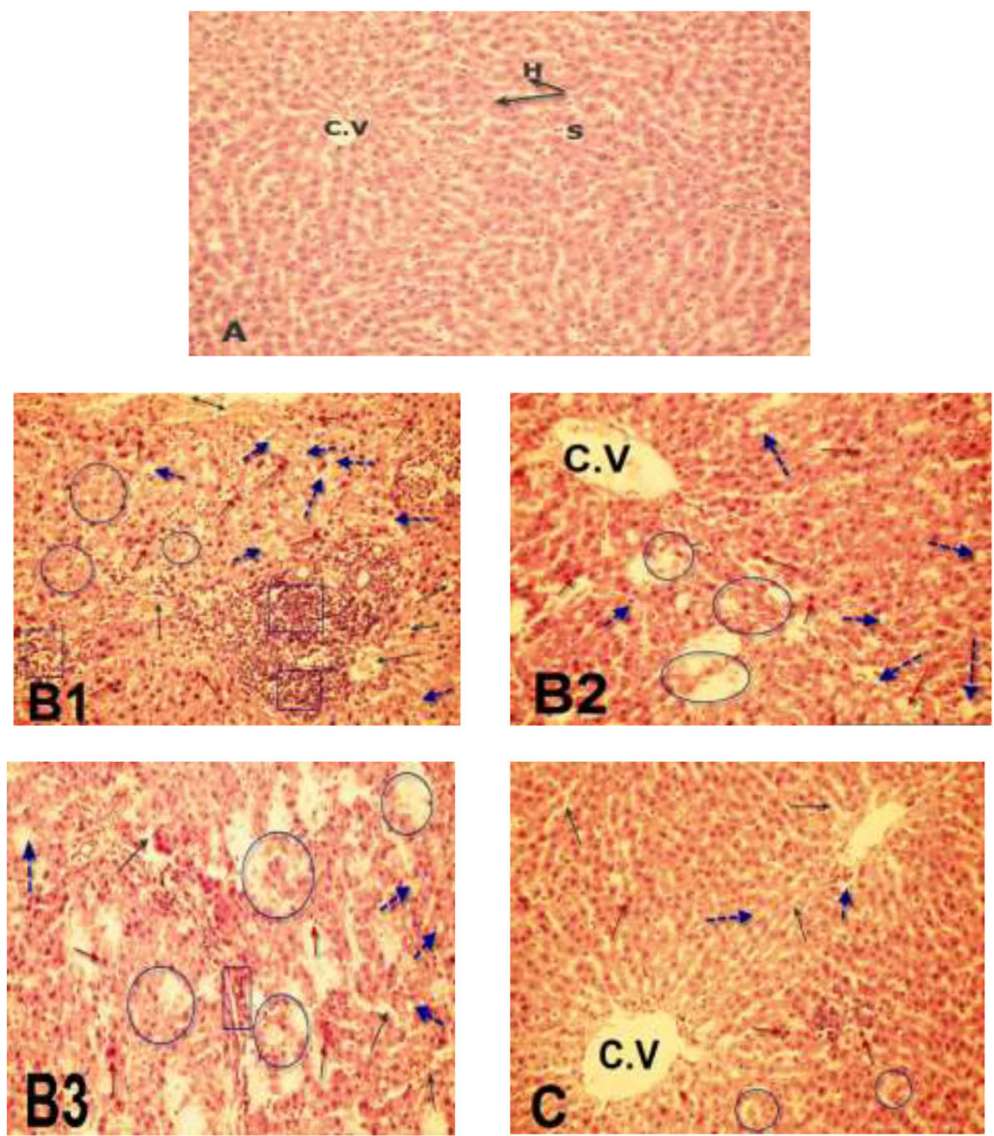

Fig. 1 Light micrographs of the liver tissues of rats treated as follow: liver tissue of control group (A) showing normal hepatocytes architecture, central vein (c.v), normal blood sinusoids (S), and hepatocytes $(H)$. (B1, B2, and B2) Liver tissue of triton-treated rats showing distended and hemorrhage in the central vein (C.V), loss of the normal hepatocytes architecture, degenerated hepatocytes and focal necrosis (circle), pyknotic nuclei (red arrows), heptacyte vacuolization (dotted blue arrows) and dilation and hemorrhage of hepatic sinusoids (black arrows) and

lymphocytes aggregation, mononuclear cell infiltration (blue square). Histological alterations induced in triton + soybean oil-treated rats group ( $C$ ) were markedly reduced. H\&E stain. ( $\times 200)$

DNA damage was shown in Triton WR-1339-treated rats (lane 2), which may indicate a mild DNA fragmentation, compared to the control (lane 1). Interestingly, soybean oil plus Triton WR-1339 treatment (lane 3) could ameliorate the Triton WR-1339-induced damage.

\section{Discussion}

Treatment with Triton WR-1339 caused an elevation in the level of TBARS combined with inhibition in the activities of the antioxidant enzymes (GSH-Px, GST, CAT, and SOD) in rat plasma, liver, and brain. This disturbance was also manifested by significant reduction in GSH level in the plasma and the both organs, indicating increased reactive oxygen species (ROS) production and/or deficiency of the antioxidant defense system (Beyegue, Ngangoum, Kuate, Ngondi, \& Oben, 2012). They reported that Triton WR-1339 caused a significant elevation in lipid peroxide levels in both plasma and liver. The reduced glutathione is one of the first lines of cellular defense against oxidative injury. Thus, insufficient detoxification of these reactive oxygen species by the antioxidant enzymes may lead to an occurrence of imbalance between antioxidant and oxidant systems. Low reduced glutathione level could also attributed to enzyme inactivation by ROS bringing about damage to proteins. Saxena and Garg (2010) showed that tissue lipid peroxidation is a degradative phenomenon as a consequence of free radical chain production and propagation which affects mainly the polyunsaturated fatty acids. Interestingly, the antioxidant properties of soybean oil were also observed in this study through the reduction of lipid peroxides (TABRS), increased levels of reduced glutathione, and an elevation of the endogenous antioxidant enzymes (GSH-Px, GST, CAT, SOD). The decline in lipid peroxidation indicates a counteraction of the deleterious effects of lipid peroxidation by soybean oil (Cheng \& Kong, 2011). In addition, Mallo et al. (2013a) reported that the flavonoids, which are one of the components of soybean have gained importance as scavengers of free 

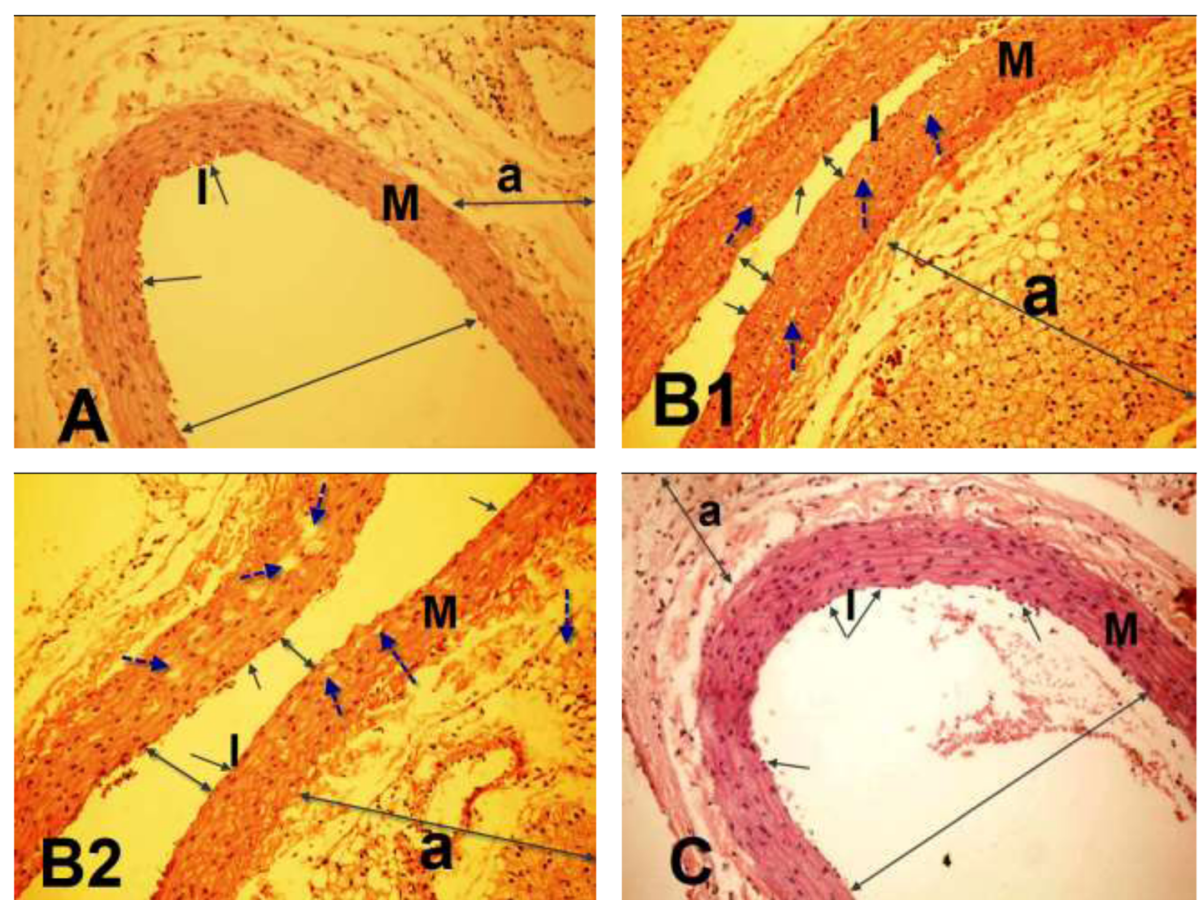

Fig. 2 Light micrographs of dorsal aorta of rats treated as follow: control (A), triton-treated rats (B1, B2), and triton + soybean oil-treated rats (C). Note: normal tunica intimal (I) with a single irregular layer of endothelial cells (black-arrows), tunica media (M) with elastic fibers and tunica adventitia (a) appear normal in control group. Loss of endothelial cells of tunica intimal (I), disorganized and vacuolation of tunica media (M), increased adventitial thickness (a), and decreased the lumen of the aorta (double headed arrows) in triton-treated rats (B1, B2) compared to normal layers of the dorsal aorta in the control group $(A)$. Histological changes induced after triton treatments were markedly reduced in the combination group triton + soybean oil-treated rats (C). (H\&E $\times 400)$

radicals and as a potent inhibitor of lipid peroxidation. Free radical scavenging enzymes such as SOD, CAT, and GSH-Px are the first line of cellular defense against oxidative injury and are involved in the disposal of superoxide anions, hydrogen peroxide, etc. (Vijayaraj, Muthukumar, Sabarirajan, \& Nachiappan, 2013). They observed pronounced alterations during the hyperlipidemic conditions in rats. Phytoestrogens may play an antioxidant role not only by scavenging reactive oxygen species but also via stimulating the activity of the antioxidant enzymes (SOD, GSH-Px , nd CAT) (Taha, Mandour, \& Lebda, 2014). The present investigation showed that all Triton

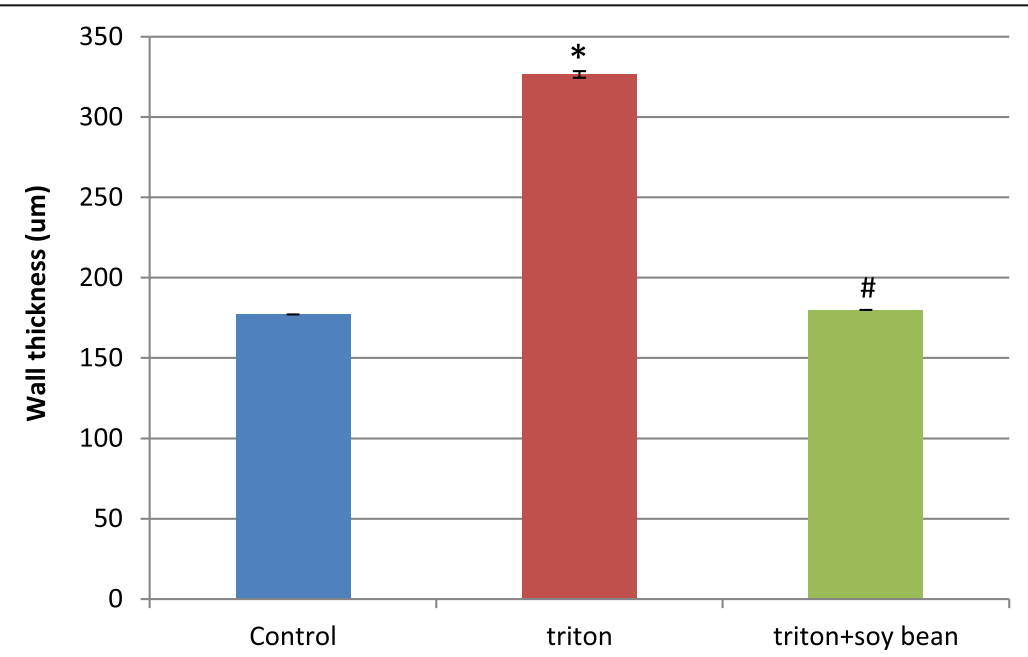

Fig. 3 Means of wall thickness of dorsal aorta of vehicle control, triton-treated rats, and triton + soybean-treated rats. Significant difference from the control group at $* P<0.05$. Significant difference from the triton-intoxicated group at $\# P<0.05$ 


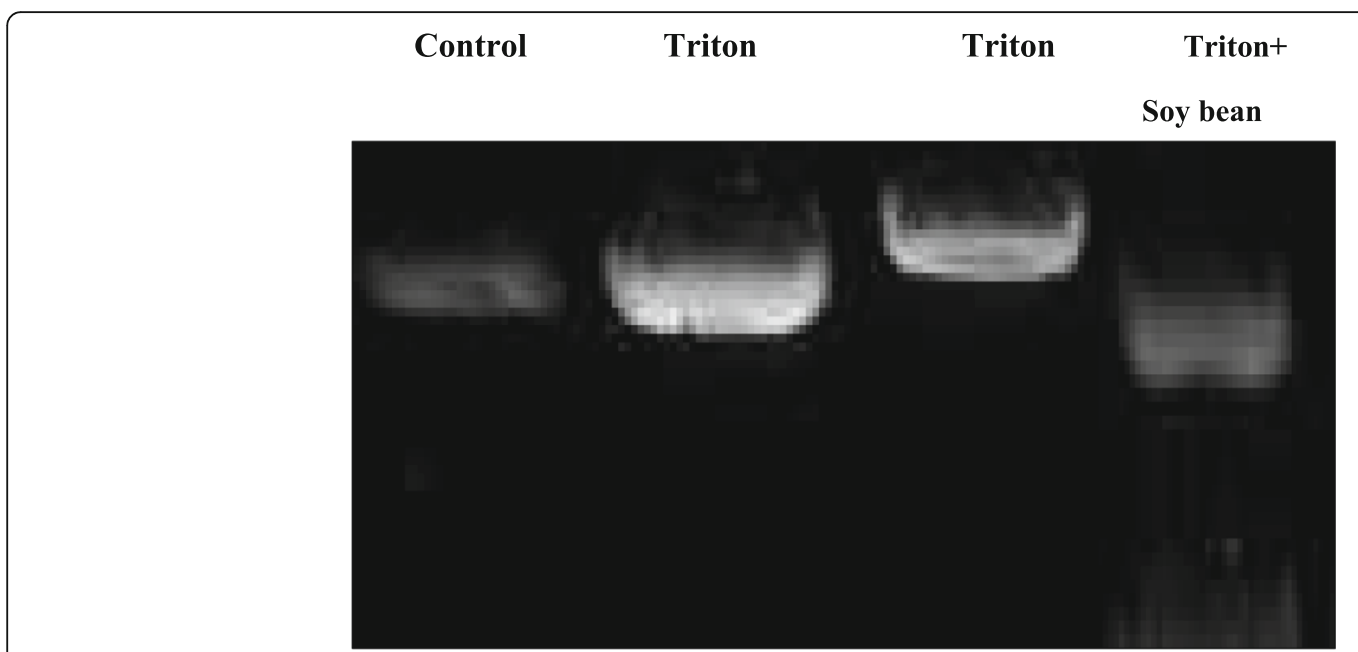

Fig. 4 Brain DNA fragmentation on agarose gel electrophoresis of the different experimental groups. The first lane: control; the second and third lanes: triton-treated rats and the fourth lane: triton + soybean-treated rats

WR-1339-induced rats displayed hyperlipidemia as shown by their elevated levels of plasma and liver cholesterol, triglyceride, VLDL, and LDL in addition to the reduction in the HDL level. Shrivastava, Chaturvedi, Singh, Saxena, and Bhatia (2013) stated that Triton WR-1339 prevents the catabolism of triacylglycerol-rich lipoproteins by lipoprotein lipase (LPL) thus, leading to blocking the removal of triacylglycerol from plasma. In general, consumption of more fat may lead to the production of increased VLDL, resulting in the formation of maximum amounts of LDL, which may stick to the walls of the blood vessels causing blockages for the normal flow of blood. The strong association between the risk of coronary artery diseases, high levels of LDL, and low levels of HDL has been well established (Igweh, Nwagha, \& Okaro, 2005). Oral administration of soybean oil in combination with Triton WR-1339, daily for 4 weeks, was found to be effective in ameliorating the lipid disturbance that was seen in the hyperlipidemic rats. These results suggested the plasma lipid-lowering and antioxidative effects of soybean oil. Vijayaraj et al. (2013) revealed that the increase in HDL and the decrease in the cholesterol, LDL, and triacylglycerol were associated with a decrease in the risk of ischemic heart diseases. A study was conducted by Nishimura, Yamaguchi, Naito, and Yamauchi (2006), indicating that soybean oil prevents an induced liver damage. In another study, it was emphasized that soybean oil regulates the blood and liver lipid level in a positive way (Lin, Tsai, \& Lin, 2005). Moreover, the reduction in lipid peroxidation by the naturally occurring dietary antioxidants was associated with hypolipidemic and antiatherogenic effects (Abhilash, Nisha, Prathapan, Nampoothiri, Cherian, Sunitha, \& Raghu, 2011). The activities of plasma AST, ALT, ALP, ACP, and $\mathrm{LDH}$ in addition to the bilirubin level were increased. These enzymes are located in the liver cells and leak out, and make their way into the general circulation when liver cells are injured. ALT is thought to be a more specific indicator of liver inflammation, since AST may be elevated in diseases of other organs such as the heart muscles. AST activity also increased when infiltration of the liver cells via damage of the mitochondria occurs (Mallo, Tanko, \& Mabrouk, 2013b). The increase in the plasma activities of these enzymes were directly proportional to the degree of cellular damage caused by hypercholesterolemia (Osman, Fayed, Ghada, \& Romeilah, 2010). Meanwhile, the activities of these enzymes were elevated in the plasma confirming the liver damage. The increase in bilirubin level may be caused by liver damage, excessive hemolytic destruction of erythrocytes, obstruction of the biliary tract (obstructive jaundice), and in drug-induced reactions (Sood, 2006). The observed reduction in the total proteins, albumin, and globulin may be associated with liver damage, nutritional deficiency, and renal failure (Sood, 2006). Since proteins are constituents of muscle, enzymes, hormones, and several other key factors, invariably these factors will be affected. The observed decreases in the levels of these parameters are confirmed by the results of Sodipo, Abdulrahman, Sandabe, and Akinniyi (2011). The changes of these parameters confirmed the liver damage which revealed signs of inflammatory cellular infiltration, vacuolated hepatocytes, dilated sinusoids, congested blood vessels, and necrosis. In addition, Triton WR-1339 caused a significant elevation in plasma urea and creatinine reflecting renal impairment. Triton WR-1339 caused a significant decline in the total protein, albumin, and globulin. Triton WR-1339 increased oxidative stress through an elevation in TBARS associated with depletion in glutathione and the activities of the antioxidant enzymes, indicating increased ROS production (Beyegue et al., 2012). The decline in the total protein can be 
explained through a direct attack of ROS, giving rise to the carbonyl group formation (Mallo, Tanko, \& Mabrouk, 2013b). The treatment with soybean plus Triton WR-1339 caused amelioration in the activities of AST, ALT, ALP, $\mathrm{ACP}$, and LDH in addition to the bilirubin level. The beneficial effects of soybean oil on lipid metabolism may be attributed to its nutritional values; particularly polyunsaturated fatty acid contents (Schmid \& Woollett, 2003). Diets enriched with polyunsaturated fatty acids (PUFAs) have been recommended by several medical and nutritional experts because of the lipid-lowering effects of PUFAs in the plasma (Schmid \& Woollett, 2003). The observed amelioration of the liver enzymes of Triton WR-1339 + soybean oil-treated rats may be due to the ability of soybean oil to protect against consequences of tissue damage resulting in normal levels of plasma AST, ALT, ALP, and LDH. The soybean oil is recommended to be rich in phytoestrogens as reported by Hassan, Wakf, and Gharib (2013). Phytoestrogens are polyphenolic compounds featuring with 1-3 hydroxyl $(-\mathrm{OH})$ groups that resemble the naturally occurring hydroxyl group on the phenol ring of estrogen. These $\mathrm{OH}$ groups attach free radicals through hydrogen electron donation resulting in stable antioxidant state (Clark, 2002). Flavonoids which are one of the components of soybean have gained importance as scavengers of free radicals and a potent inhibitor of lipid peroxidation. It has been reported that population having a high intake of isoflavones showed lower incidence of cardiovascular diseases, osteoporosis, kidney disease, and cancer risk (Shi, Gao, \& Zhao, 2007). The antioxidant effect of soybean may be attributed to soy isoflavones (Vega-López et al., 2005) and saponins (Jun, Kim, \& Sung, 2002). Soybean isoflavones have antioxidant activity through their phenolic structure, which exert direct vascular atheroprotective effects by inhibiting endothelial dysfunction through quenching ROS and reversing the imbalance between increased oxidative stress and impaired antioxidant status to maintain the redox balance of normal cells (Massaro et al., 2002). Furthermore, soybean rich in specific components with anti-inflammatory and antioxidant properties may play a role in attenuating the risk of cardiac dysfunction associated with ovariectomized rats (Oluba, Adeyemi, Ojieh, \& Isiosio, 2008). Such effects of soybean oil may be attributed to the inhibiting activity of the phenolic compounds against a number of inflammatory mediators released by endothelial cells (Romier-Crouzet et al., 2009). Other mechanisms have been suggested to explain the antioxidant activity of soybean oil including (1) protection of LDL from oxidative modification, either directly or with interaction with endogenous antioxidants like vitamin E (Rajasekhar, Rao, Latheef, Saibaba, \& Subramanyam, 2004), (2) reduction of microphage uptake of oxidizing LDL (Ros et al., 2004), and increase in size of LDL that becomes less pro-atherogenic and lowers the risks of cardiac dysfunction (Duvall, 2005; Quan, Yin, \& Kanazawa, 2009). Histological analysis was used to examine the bad effect of Triton WR-1339 on the hepatocytes. Figure 1(B1, B2, B3) revealed that Triton WR-1339 induced severe histopathological changes in the liver. These changes included disruption of the liver architecture such as cellular infiltration and cells turned into large cytoplasmic vacuoles, distended and hemorrhage of central veins, and hepatic sinusoids when compared with the control. The histological observations were parallel to the obtained biochemical findings. Inductions of hyperlipidemia in rats showed severe fatty changes in liver hepatocytes. This effect may be due to the accumulation of abundant fat droplets in hepatocytes, which occupied the entire cell cytoplasm (Kumar et al., 2009). They described the histopathological alterations in liver of rats that were treated with Triton WR-1339 as follows: sinusoidal dilation and congestion inflammatory infiltrate of mononuclear cells. This further supports the fact that Triton WR-1339 causes serious detrimental effects on the hepatocytes. In addition, the present results were supported by other studies, which indicated that a fatty diet considered as the main source of hepatocellular injury, vascular dilation, inflammation, and fibrosis outcomes were determined following this injury (Al-Awadi, Rashid, \& Hassen, 2013b). Injury to liver tissues due to hyperlipidemia alters their transport functional capacity and membrane permeability or rather integrity, leading to leakage of the enzymes from the hepatocytes cells. Therefore, the marked release of AST, ALT, and $\gamma \mathrm{GT}$ into the circulation indicates severe damage to the hepatic tissue membranes (Nishi et al., 2002). However, liver of rats treated with Triton WR-1339 + soybean oil revealed marked reduction in that the histological alterations induced in Triton WR-1339-treated group. Thus, soybean oil prevents liver damage (Kosif, Yilmaz, Evrendilek, \& Diramali, 2010). Triton WR-1339-treatment induced histopathological changes in the dorsal aorta (Fig. 2(B1, B2)) such as sclerotic changes in the walls and atrophy of elastic fibers. This was appreciated by the changes as well as the fragmentation, disintegration, and vacuolation in the tunica medial and advential with a marked increase in the tunica medial and adventitial layers thickness, which showed many lipid-containing cells. The quantitative analysis of the aortic atherosclerotic composition of this group showed a significant $(P<0.05)$ increase in the mean wall thickness indicating a degree of atherosclerosis. These results corroborated with those of Al-Awadi, Hassen, and Rashid (2013a) who revealed the presence of fatty streaks, infiltration of fat laden cells (foam cells) in a subintimal layer of the coronary arteries of positive control rats fed on high fat diet. On the other hand, the morphometric analysis of the dorsal aorta of the combination group (Triton WR-1339 + soybean oil) revealed that some of the 
histological alterations induced after Triton WR-1339 treatment were markedly reduced (Fig. $2(\mathrm{C})$ ). These results could be confirmed by the significant $(P<0.05)$ decrease in the mean wall thickness which is equal to $179.86 \pm 0.43 \mu \mathrm{m}$. The current data demonstrated that soybean oil can protect against atherosclerotic plaque deposition in the dorsal aorta. The protective effects of soybean could be attributed to its antioxidant nature that combines free radical scavenging properties (Jaarin, Norhayati, Norzana, Aini, \& Ima-Nirwana, 2006). Adam, Das, Othman, and Jaarin (2009) suggested that fresh soy oil may have a protective effect on the muscle growth, but such protective effects are lost when the oil is repeatedly heated. They showed that feeding with soy oil did not result in any significant differences in tunica intima thickness. The present study also proved that Triton WR-1339 caused a decline in the activities of the AChE and MAO enzymes in rat plasma and brain extract. Treatment with Triton WR-1339 plus soybean oil caused elevation in plasma and brain AChE and MAO activities compared to the Triton WR-1339-treated group. Carbonell and Rama (2007) showed that the activity of AChE was inhibited by free radical formation. This might upset the pro-oxidant and antioxidant balance within the brain, which could be one of the reasons for decreased AChE activity. Simultaneous supplementation of soybean oil retrieved both AChE as well as MAO activities due to its free radical scavenging capacity (Venkataraman, Krishnamoorthy, Vengatesh, Srinivasan, Aruldhas, \& Arunakaran, 2008). Figure 4 showed mild DNA fragmentation that indicates Triton-induced neurotoxicity in brain tissues (lane 2) as compared to the control (lane 1).While, Triton WR-1339 plus soybean oil treatment (lane 3) caused partial inhibition in the DNA fragmentation compared to the Triton WR-1339-treated group (lane 2). In further support of our results, a previous study indicated that Triton WR-1339 efficiently induced DNA degradation indicating its necrotic effect (Abdou \& Wahby, 2016). Thus, the increase in lipid peroxidation and depletion of antioxidant enzymes play major role in Triton WR-1339-induced genotoxicity. The protective effects of soybean oil against genotoxicity of Triton WR-1339 could be due to its capability of decreasing the oxidative stress (Mallo, Mabrouk, et al., 2013a).

\section{Conclusion}

The present study concluded that Triton WR-1339 resulted in hyperlipidemia combined with its adverse effects such as the alterations of the biochemical parameters and histological and genomic DNA damage. Soybean oil showed potent antioxidant activity and protective effects because of their power to correct hyperlipidemia. It would be worthwhile to investigate the effect of soybean oil supplementation in a randomized clinical trial with patients.

\section{Abbreviations}

HDL-C: High-density lipoprotein; AChE: Acetylcholinesterase; ALT: Alanine amino transaminase; AST: Aspartate aminotransaminase; CAT: Catalase; GSH: Reduced glutathione; LDH: Lactate dehydrogenase; LDL-c: Low density lipoprotein; SOD: Superoxide dismutase; TBARS: Thiobarbituric acid-reactive substances

\section{Acknowledgments}

The authors gratefully acknowledge histological analysis by Prof. Dr. M.A.H. Yehia and molecular analysis by Medical Research Institute, Alexandria University.

\section{Funding}

This research is funded by the private partnership. Also, the research received no specific funding from any agency in the public, commercial.

\section{Availability of data and materials}

All the data and material were available. The data of this article are included within the article and its additional files.

\section{Authors' contributions}

HMA and AAN were responsible for the idea, the design of the study, writing, and revising the manuscript. MIY performed experiments and made the statistical analysis for the data. All authors have read and approved the manuscript.

\section{Ethics approval and consent to participate}

The local committee approved the design of the experiments, and the protocol conforms to the guidelines of the National Institutes of Health $(\mathrm{NIH})$.

\section{Consent for publication}

All co-authors agree to publish this manuscript in the Journal of Basic and Applied Zoology.

\section{Competing interests}

The authors declare that they have no competing interests.

\section{Publisher's Note}

Springer Nature remains neutral with regard to jurisdictional claims in published maps and institutional affiliations.

\section{Author details}

'Zoology Department, Faculty of Science, Alexandria University, Alexandria, Egypt. ${ }^{2}$ Department of Environmental Studies, Institute of Graduate Studies and Research, Alexandria University, 163 Horreya Avenue, Chatby, P.O.Box 832, Alexandria 21526, Egypt. ${ }^{3}$ Department of Biochemistry, Faculty of Science, Alexandria University, Alexandria, Egypt.

Received: 13 October 2017 Accepted: 7 November 2018

Published online: 29 November 2018

\section{References}

Abdou, H. M., \& Wahby, M. M. (2016). Neuroprotection of grape seed extract and pyridoxine against triton-induced neurotoxicity. Oxidative Medicine and Cellular Longevity, 2016, 1-8

Abhilash, P. A. Nisha, P. Prathapan, A. Nampoothiri, S. V. Cherian, O. L. Sunitha, T. K., \& Raghu, K. G. (2011). Cardioprotective effects of aqueous extract of Oxalis corniculata in experimental myocardial infarction. Experimental and Toxicologic Pathology, 63, 535-540.

Adam, S. K., Das, S., Othman, F., \& Jaarin, K. (2009). Fresh soy oil protects against vascular changes in an estrogen-deficient rat model: an electron microscopy study. Clinics, 64, 1113-1119.

Al-Awadi, J. H. H., Hassen, A. J., \& Rashid, K. H. (2013). Obesity and inflammation induces by high fat diet concomitant with mild fatty streak in coronary artery: immuno-histopathological study. Kerbala Journal of Pharmaceutical Sciences, 6, 9-20.

Al-Awadi, J. H. H., Rashid, K. H., \& Hassen, A. J. (2013). High fat diet induce hyperlipidemia incidences with sever changes in liver tissue of male albino rats: a histological and biochemical study. Kerbala Journal of Pharmaceutical sciences, 6, 21-32. 
Beutler, E., Duron, O., \& Kelly, B. M. (1963). Improved method for the determination of blood glutathione. The Journal of Laboratory and Clinical Medicine, 61, 882-888.

Beyegue, C. N., Ngangoum, R. C., Kuate, D., Ngondi, J. L., \& Oben, J. E. (2012). Effect of Guibourtia tessmannii extracts on blood lipids and oxidative stress markers in triton WR 1339 and high fat diet induced hyperlipidemic rats. Biology and Medicine, 4, 1.

Bhuvaneswari, R., \& Sasikumar, K. (2013). Antihypolipidemic activity of aegle marmelos $(\mathrm{L})$ Corr., leaf extract in triton WR-1339 induced hypolipidemic rats. Pharmacie Globale (IJCP), 3, 1-3.

Carbonell, T., \& Rama, R. (2007). Iron, oxidative stress and early neurological deterioration in ischemic stroke. Current Medicinal Chemistry, 14, 857-874.

Chahoud, G., Aude, Y. W., \& Mehta, J. L. (2004). Dietary recommendations in the prevention and treatment of coronary heart disease: do we have the ideal diet yet? The American Journal of Cardiology, 94, 1260-1267.

Cheng, D., \& Kong, H. (2011). The effect of Lycium barbarum polysaccharide on alcohol-induced oxidative stress in rats. Molecules, 16, 2542-2550.

Chiu, D. T., Stults, F. H., \& Tappel, A. L. (1976). Purification and properties of rat lung soluble glutathione peroxidase. Biochimica et Biophysica Acta (BBA)Enzymology, 445, 558-566.

Clark, S. F. (2002). The biochemistry of antioxidants revisited. Nutrition in Clinical Practice, 17, 5-17.

Da Rocha, J. T., Sperança, A., Nogueira, C. W., \& Zeni, G. (2009). Hypolipidaemic activity of orally administered diphenyl diselenide in Triton WR-1339-induced hyperlipidaemia in mice. Journal of Pharmacy and Pharmacology, 61, 1673-1679.

Duncan, D. B. (1957). Multiple range tests for correlated and heteroscedastic means. Biometrics, 13, 164-176.

Duvall, W. L. (2005). Endothelial dysfunction and antioxidants. The Mount Sinai Journal of Medicine, New York, 72, 71-80.

Ellman, G., Courtney, K., Anders, V., \& Featherstone, R. (1961). A new rapid colorimetric determination of acetylcholinesterase activity. Biochemical Pharmacology, 7, 88-95.

Esterbauer, H. and Cheeseman, K.H. (1990). Determination of aldehydic lipid peroxidation products:malonaldehyde and 4-hydroxynonenal. In Methods in enzymology. Academic Press, 186, 407-421.

Habig, W. H., Pabst, M. J., \& Jakoby, W. B. (1974). Glutathione S-transferases the first enzymatic step in mercapturic acid formation. Journal of Biological Chemistry, 249, 7130-7139.

Hassan, H. A., Wakf, A. M. E., \& Gharib, N. E. E. (2013). Role of phytoestrogenic oils in alleviating osteoporosis associated with ovariectomy in rats. Cytotechnology, 65, 609-619.

Hayes, K. C., \& Khosla, P. (2007). The complex interplay of palm oil fatty acids on blood lipids. European Journal of Lipid Science and Technology, 109, 453-464.

Ibrahim, S. R., Mohamed, G. A., Banjar, Z. M., \& Kamal, H. K. (2013). Natural antihyperlipidemic agents: current status and future perspectives. Phytopharmacology, 4, 492-531.

Igweh, J. C., Nwagha, I. U., \& Okaro, J. M. (2005). The effects of menopause on the serum lipid profile of normal females of South East Nigeria. Nigerian Journal of Physiological Sciences, 20, 48-53.

Jaarin, K., Norhayati, M., Norzana, G., Aini, U., \& Ima-Nirwana, S. (2006). Effects of heatedvegetable oils on serum lipids. Pakistan Journal of Nutrition, 5, 19-29.

Jun, H. S., Kim, S. E., \& Sung, M. K. (2002). Protective effect of soybean saponins and major antioxidants against aflatoxin B1-induced mutagenicity and DNAadduct formation. Journal of Medicinal Food, 5, 235-240.

Kosif, R., Yilmaz, F., Evrendilek, A. G., \& Diramali, M. (2010). Histopathological effects of Aloe barbadensis and soybean oil on rat liver. International Journal of Morphology, 28, 1101-1106.

Küçükgergin, C., Aydın, A. F., Özdemirler-Erata, G., Mehmetçik, G., Koçak-Toker, N., \& Uysal, M. (2010). Effect of artichoke leaf extract on hepatic and cardiac oxidative stress in rats fed on high cholesterol diet. Biological Trace Element Research, 135, 264-274.

Kumar, V., Singh, P., Chander, R., Mahdi, F., Singh, S., Khanna, A. K., ... Singh, R. K. (2009). Hypolipidemic activity of Hibiscus rosanensis root in rats. Indian Journal of Biochemistry \& Biophysics, 46, 507-510.

Lillie RD. (1965). Histopathological technique and practical histochemistry, third edition. Blakistar Division of McGraw- Hill Book Co: Toronto, London, New York.

Lin, C. Y., Tsai, C. Y., \& Lin, S. H. (2005). Effects of soy components on blood and liver lipids in rats fed high-cholesterol diets. World Journal of Gastroenterology, 11, 5549.

Lowry, O. H., Rosebrough, N. J., Farr, A. L., \& Randall, R. J. (1951). Protein measurement with the Folin phenol reagent. Journal of Biological Chemistry, 193, 265-275.
Mallo, M. J., Mabrouk, M. A., Tanko, Y., \& Mshelia, P. P. (2013). Effects of soya bean oil and vitamin $\mathrm{C}$ on lipid peroxidation and antioxidant biomarkers ethanolinduced oxidative stress in Wistar rats. Journal of Pharmacy and Biological Sciences, 4, 28-31.

Mallo, M. J., Tanko, Y., \& Mabrouk, M. A. (2013). Ameliorative effects of soya bean oil and vitamin $C$ on liver enzymes in ethanol-induced oxidative stress in Wistar rats. Journal of Pharmacy and Biological Sciences, 3, 34-37.

Massaro, M., Basta, G., Lazzerini, G., Carluccio, M. A., Bosetti, F., Solaini, G., ... De Caterina, R. (2002). Quenching of intracellular ROS generation as a mechanism for oleate-induced reduction of endothelial activation and early atherogenesis. Thrombosis and Haemostasis, 88, 335-344.

Miller, S. A., Dykes, D. D., \& Polesky, H. F. R. N. (1988). A simple salting out procedure for extracting DNA from human nucleated cells. Nucleic Acids Research, 16, 1215.

Misra, H. P., \& Fridovich, I. (1972). The role of superoxide anion in the autoxidation of epinephrine and a simple assay for superoxide dismutase. Journal of Biological Chemistry, 247, 3170-3175.

Nishi, K., Uno, M., Fukuzawa, K., Horiguchi, H., Shinno, K., \& Nagahiro, S. (2002) Clinicopathological significance of lipid peroxidation in carotid plaques. Atherosclerosis, 160, 289-296.

Nishimura, M., Yamaguchi, M., Naito, S., \& Yamauchi, A. (2006). Soybean oil fat emulsion to prevent TPN-induced liver damage: possible molecular mechanisms and clinical implications. Biological and Pharmaceutical Bulletin, $29,855-862$.

Oluba, O. M., Adeyemi, O., Ojieh, G. C., \& Isiosio, I. O. (2008). Fatty acid composition of Citrullus lanatus (egusi melon) and its effect on serum lipids and some serum enzymes. International Journal of Cardiology, 5, 2-10.

Osman, M., Fayed, S. A., Ghada, I. M., \& Romeilah, R. M. (2010). Protective effects of chitosan, ascorbic acid and gymnema sylvestre against hypercholesterolemia in male rats. Australian Journal of Basic and Applied Sciences, 4, 89-98.

Pushpa, I., \& Jayachitra, J. (2015). Hypolipidemic and antioxidant activity of phoenix dactylifera $\mathrm{L}$ in albino wistar rats. World Journal of Pharmacy and Pharmaceutical Sciences, 4, 790-798.

Quan, J., Yin, X., \& Kanazawa, T. (2009). Effect of soybean hypocotyl extract on lipid peroxidation in gk rats. Journal of Clinical Biochemistry and Nutrition, 44, 212.

Rajasekhar, D., Rao, P. V. S., Latheef, S. A., Saibaba, K. S., \& Subramanyam, G. (2004) Association of serum antioxidants and risk of coronary heart disease in south Indian population. Indian Journal of Medical Sciences, 58, 465.

Romier-Crouzet, B., Van De Walle, J., During, A., Joly, A., Rousseau, C., Henry, O., \& Schneider, Y. J. (2009). Inhibition of inflammatory mediators by polyphenolic plant extracts in human intestinal Caco-2 cells. Food and Chemical Toxicology, 47, $1221-1230$

Ros, E., Núñez, l., Pérez-Heras, A., Serra, M., Gilabert, R., Casals, E., \& Deulofeu, R. (2004). A walnut diet improves endothelial function in hypercholesterolemic subjects a randomized crossover trial. Circulation, 109, 1609-1614.

Salem, H.R.A., El-Raouf Mohamed, A.A., Saleh, E. M. and Shalaby, K. A. ( 2012). Influence of Hesperidin combined with Sinemet on geneticle and biochemical abnormalities in rats suffering from Parkinsons disease. Life Science Journal, 9(4), 930-945.

Sandler, M., Reveley, M. A., \& Glover, V. I. V. E. T. T. E. (1981). Human platelet monoamine oxidase activity in health and disease: a review. Journal of Clinical Pathology, 34, 292-302.

Saxena, R., \& Garg, P. (2010). Vitamin E provides protection against in vitro oxidative stress due to pesticide (Chlorpyrifos and Endosulfan) in goat RBC. Bull Biosci, 1, 1-6.

Schmid, K. E., \& Woollett, L. A. (2003). Differential effects of polyunsaturated fatty acids on sterol synthesis rates in adult and fetal tissues of the hamster: consequence of altered sterol balance. American Journal of PhysiologyGastrointestinal and Liver Physiology, 285(5), G796-G803.

Shi, G., Gao, G., \& Zhao, Z. (2007). Apoptosis of endothelial cells of cerebral basilar arteries in symptomatic cerebral vasospasm rabbit models: Electron microscopic observation. Neural Regeneration Research, 2, 479-482.

Shrivastava, A., Chaturvedi, U., Singh, S. V., Saxena, J. K., \& Bhatia, G. (2013). Lipid lowering and antioxidant effect of miglitol in triton treated hyperlipidemic and high fat diet induced obese rats. Lipids, 48, 597-607.

Sodipo, O. A., Abdulrahman, F. I., Sandabe, U. K., \& Akinniyi, J. A. (2011). Biochemical liver function with aqueous fruit extract of Solanum macrocarpum linn in albino rats acutely administered triton-x to induce hyperlipidaemia. Journal of Applied Pharmaceutical Science, 1, 89-93.

Sood, R. (2006). Textbook of medical laboratory technology, (pp. 609-672). New Delhi: Jaypee Brothers Medical Publishers. 
Sunil, C., Ignacimuthu, S., \& Kumarappan, C. (2012). Hypolipidemic activity of Symplocos cochinchinensis S. Moore leaves in hyperlipidemic rats. Journal of Natural Medicines, 66, 32-38.

Taha, N. M., Mandour, A. A., \& Lebda, M. A. (2014). Antioxidative and cardioprotective effects of ethanolic extract of ginger on triton WR-1339 induced hyperlipidemia in rats. International Journal of Chemical Research, 6, 153-158.

Vega-López, S., Yeum, K. J., Lecker, J. L., Ausman, L. M., Johnson, E. J., Devaraj, S., ... Lichtenstein, A. H. (2005). Plasma antioxidant capacity in response to diets high in soy or animal protein with or without isoflavones. The American Journal of Clinical Nutrition, 81, 43-49.

Venkataraman, P., Krishnamoorthy, G., Vengatesh, G., Srinivasan, N., Aruldhas, M. M., \& Arunakaran, J. (2008). Protective role of melatonin on PCB (Aroclor 1254) induced oxidative stress and changes in acetylcholine esterase and membrane bound ATPases in cerebellum, cerebral cortex and hippocampus of adult rat brain. International Journal of Developmental Neuroscience, 26, 585-591.

Vijayaraj, P., Muthukumar, K., Sabarirajan, J., \& Nachiappan, V. (2013). Antihyperlipidemic activity of Cassia auriculata flowers in triton WR 1339 induced hyperlipidemic rats. Experimental and Toxicologic Pathology, 65, 135-141.

Warner, K. (2005). Effects on the flavor and oxidative stability of stripped soybean and sunflower oils with added pure tocopherols. Journal of Agricultural and Food Chemistry, 53(26), 9906-9910.

Xu, J. B., Yuan, X. F., \& Lang, P. Z. (1997). Determination of catalase activity and catalase ihibition by ultraviolet spectrophotometry. Chinese Environmental Chemistry, 16, 73-76.

Zainuddin, A. S., Massi, M. N., Alam, G., Djawad, K., \& Yusuf, I. (2015). Soybean protective effect to 8-OHdG on UVB induced-hairless mice. American Journal of Medical and Biological Research, 3, 146-148.

\section{Submit your manuscript to a SpringerOpen ${ }^{\circ}$ journal and benefit from:}

- Convenient online submission

- Rigorous peer review

- Open access: articles freely available online

- High visibility within the field

- Retaining the copyright to your article

Submit your next manuscript at $\boldsymbol{\nabla}$ springeropen.com 